\title{
Human Resource Management in Integrated Islamic Junior High School
}

\author{
Sumirah ${ }^{1}$, Jamrizal ${ }^{2}$, Ely Surayya ${ }^{3}$, Syamsulhuda ${ }^{4}$, Anggi Fitri ${ }^{5}$ \\ DOI: $10.35445 /$ alishlah.v13i3.1552
}

\section{Article Info}

Keywords: Management; Human Resources; Teachers; SMPIT

Kata kunci:

Manajemen;

$S D M$;

Guru;

SMPIT

\section{Abstract}

This study aims to determine how teachers can implement human resource management (HR) at the Integrated Islamic School (SIT). This study focuses on teacher human resources at a Junior High School (SMPIT) Jambi. This research is descriptive qualitative research. The data collection techniques used were observation, interviews, and documentation, while the data analysis techniques used were data reduction, data presentation, and conclusion drawing. The results of the field research show that the implementation of teacher HR management at SMPIT Al Fatih Jambi has not been implemented perfectly, judging from the performance of the teachers and the lack of firmness of a leader or principal. Several things must be considered, especially with regard to the selection process, placement, and teacher performance.

\section{Abstrak}

Penelitian ini bertujuan untuk mengetahui bagaimana implementasi manajemen sumber daya manusia (SDM) guru di Sekolah Islam Terpadu (SIT). Penelitian ini berfokus pada SDM Guru yang ada di Sekolah Menengah Pertama Islam Terpadu di Jambi. Penelitian ini merupakan penelitian kualitatif deskriptif. Teknik pengumpulan data yang digunakan adalah observasi, wawancara, dan dekumentasi, sedangkan teknik analisis data yang digunakan adalah reduksi data, penyajian data dan penarikan kesimpulan. Hasil penelitian lapangan menunjukkan bahwa implementasi manajemen SDM guru terlihat belum terlaksana dengan sempurna, dilihat dari kinerja para guru-guru dan kurang tegasnya seorang pemimpin atau kepala sekolah. Ada beberapa hal yang harus diperhatikan terutama berkaitan dengan proses seleksi, penempatan, dan kinerja guru.

\footnotetext{
${ }^{1}$ Universitas Islam Negeri Sulthan Thaha Saifuddin, Jambi, Indonesia

Email: drsumirah21@gmail.com

${ }^{2}$ Universitas Islam Negeri Sulthan Thaha Saifuddin Jambi, Indonesia

Email: jamrizal15@gmail.com

${ }^{3}$ Universitas Islam Negeri Sulthan Thaha Saifuddin Jambi, Indonesia

Email: surayya.ely69@gmail.com style

${ }^{4}$ Universitas Islam Negeri Sulthan Thaha Saifuddin Jambi, Indonesia

Email: syamsulhuda@uinjambi.ac.id

${ }^{5}$ Sekolah Tinggi Ilmu Tarbiyah Al-Kifayah, Riau, Indonesia

Email: anggifitri73@stit-alkifayahriu.ac.id
} 


\section{INTRODUCTION}

The ultimate goal of education is to raise the level of human capital available for use in society's various endeavors. It's a deliberate effort to build the human capital needed to compete in the global economy. (Tobari, Kristiawan, \& Asvio, 2018). The quality of a country's workforce is essential to its growth (Asvio, Yamin, \& Risnita, 2019). Education also plays an important strategic role in that it helps mold people's character and outlook for the better. If the community has a positive outlook and character, national development goals will be more likely to be met.

Human resource management is a form of acknowledgment of the importance of organizational members as resources that can support organizational goals implementation of organizational functions and activities to ensure that they are used effectively and fairly for the benefit of the organization, individuals, and society. As a formal educational institution, in the implementation of education in schools, the emphasis is on improving quality in response to the needs and dynamics of a developing society, so that improving the quality of human resources can be realized through the implementation of management (Osagie \& Okafor, 2015; Runhaar, 2017).

According to current data, Indonesia's educational level remains low compared to other countries throughout the world. According to the results of a PISA (Program for International Student Assessment) survey on the world's secondary education system, Indonesia ranks 74th out of 79 countries (Kemendikbud, 2019). It can be concluded that Indonesia is in the 6th lowest position among other developing countries. This has a huge impact on advancing people's lives in all aspects of life. So the government took the initiative to find a solution in dealing with this problem. This is in line with the vision of national education which has a desire to produce intelligent and competitive Indonesian people or perfect people by 2025 .

When it comes to the issue of human resource development, there are two factors to consider quantity and quality. Lack of human resources and inadequate infrastructure and insufficient finances are the most important obstacles to progress in a field (Motkuri, Vardhan, \& Ahmad, 2018). The low quality of human resource education in the health sector can be a contributor to the infant mortality rate in China (Anand, Fan, Zhang, Ke, Dong, \& Chen, 2008). Thus it can be concluded that the quality of these human resources must accompany the quantity of human resources.

When a child is a young child, their educational style is influenced by the quality of their early education. However, the quality of education is influenced by many factors, including teachers, the number of students in each class, the curriculum, the completeness of books, the facilities and infrastructure used, and other gadgets, both hardware, and software. The idea that the quality of an educational institution's management has an effect on the quality of its instruction is what spurs the demand for high-quality educational management.

HR management is implemented to produce high-quality human resources that meet the school's objectives and expectations. Educators should be managed effectively and correctly because they are the spearhead who will lead educational activities. They are the direct focus of educational activities. They will also play a critical role in mobilizing additional educational resources (Bastian, 2009). As a result, professional human resource management at educational institutions is a must that must always be enhanced. As with teacher qualifications, some teachers in Islamic schools are required not to satisfy the criteria for a teacher who is in accordance with their scientific background or not in their field of skill, such as a certified Religion and Physical Education teacher. In order to prepare effective human resources, a leader or principal must provide particular coaching to these teachers.

In light of the teacher's pivotal role, the implementation of teaching and learning activities in Islamic schools will be able to meet the established requirements if the school is able to prepare teacher resources based on their qualifications appropriately. It is vital to manage teacher resources and implement them effectively carefully to achieve these goals. The authors are interested in examining one of the Integrated Islamic Schools (SIT) in Teacher HR Implementation at the school based on these considerations. SIT is an Islamic school that fosters students' character and 
competency by integrating Islamic beliefs and teachings into a curriculum built around an effective learning strategy and optimal and cooperative interaction between teachers, parents, and the community (JSIT, 2016).

HR management plays a critical function in any company. The development and achievement of an organization's goals are determined by qualified human resources. Similarly, at a school, teacher resources play a critical role in fulfilling objectives (Viterouli, Belias, \& Koustelios, 2021). For this reason, teacher resources must be arranged to work together to integrate with all school components to advance the school. When it comes to human resources (teachers), excellent resources are demonstrated by good performance and productivity, among other things. The quality of a person's task and work-oriented conduct affects their performance. Similarly, in the case of teacher performance, this instructor's performance can be evaluated from two perspectives: administration and professional development. Because performance is the physical manifestation of the work done by individuals or organizations, it is vital to seek to enhance the performance of the factors that influence remuneration, such as performance, quality of performance, and work motivation.

Efforts to increase human resource quality must be followed to improve education and teaching. With the government's commitment to play a role in improving the quality of education and teachers, as well as efforts to improve the quality of education and teachers, it is hoped that in the future, there will be a generation that is smart, creative, and competitive to help build the nation and state in order to realize nations and developed countries. Teacher professionalism is a requirement that cannot be postponed any longer, given the increasing competition that is becoming more difficult in the age of globalization, in accordance with the capacity it possesses to play a maximum role, including teaching as a profession that requires its own set of skills and expertise. Professionalism is a necessity for every individual in the context of increasing the quality of human life, not merely because of the needs of the times. Professionalism necessitates sincerity and sufficient competence for someone to be deemed worthy of performing a task (Marselinus, 2011).

Previous researchers have put forward research on teacher HR Management has been put forward previous researchers, Ramang (2020) report that good management of teacher resource development in terms of achievement management, reward management, and training and development. Teacher HR management can also be accomplished by improving the organization's effectiveness, as Mukhtar, Risnita, \& Prasetyo (2020) discovered that leadership and communication elements distinguish organizational effectiveness. Organizational commitment can also boost teacher HR management through the principal's leadership style, teacher emotional intelligence, and teacher work satisfaction (Asvio et al., 2019).

The HR management success of SMA Muhammadiyah 1, South Sumatra Province, is outstanding. SMA Muhammadiyah 1 South Sumatra Province has effectively implemented a performance management approach that can increase teacher performance by innovating teacher HR management. The teacher performance management model, POAC management, demonstrates its success (Planning, Organizing, Actuating, and Controlling). Other factors that have been found to contribute to the success of teacher performance management include HR competence, motivation in managing teacher performance, the effectiveness of performance management starting with input, processes, and teacher performance goals, as well as the use of facilities and infrastructure, time, and finance (capital) (Rulitawati, Ritonga, \& Hasibuan, 2020).

This study supports Dessler's (2014) theory, which states that human resource management is the process of hiring, training, evaluating, and compensating people while also paying attention to their work relationships, health and safety, and equity concerns. Ivancevich (2010) proposed an HR acquisition theory that included: 1) HR planning and alignment; 2) job analysis and design; 3) recruitment; and 4) selection. Training and development, as well as career planning and development, are two aspects of HR development. Ivancevich's viewpoint is similar to that of Priyono 
(2010), who stated that HR management's functions include: 1) planning for HR needs; 2) staffing according to the organization's needs; 3) performance appraisal; 4) improvement of worker quality and working environment; and 5) achievement of effective working relationships. This viewpoint is also consistent with the theories: 1) Job analysis; 2) HR planning; 3) employee recruiting; 4) employee selection process; 5) education and training; 6) employee performance review; and 7) remuneration are all significant aspects of HR management, according to Syafri and Alwi (2014). HR management is concerned with creating planning systems, employee preparation, staff development, career management, performance evaluation, employee compensation, and excellent labor relations, according to Rusby (2016). HR management for teachers starts with the HR planning process, followed by the selection process, training, placement, and organization.

In this era of disruption, teacher HR management research at SIT is critical to explore. This is due to SIT's ability to develop character-driven human resources through character-driven human resources for teachers. SIT is the ideal medium for totally humanizing people. SIT's curriculum is able to combine aqliyah, ruhiyah, and bodily education, which means that SIT aims to educate students to become children who develop their intellectual and intellectual abilities, improve the quality of their faith and devotion to Allah SWT, develop noble character, and have health, fitness, and skills in everyday life (JSIT, 2016).

This study aid in the development of teacher HR management innovations, which is especially crucial in this era of disruption. Beginning in 2020, the era of disruption is described as one in which large and fundamental changes in the overall order of people's lives occur. Changes in the Disruption Era are more akin to a volcanic eruption, which destroys the old ecosystem and replaces it with a new one that is inversely proportionate to the old (Rokhman, 2017). Teacher HR management at SIT will be easier to face challenges in this era of disruption with a combination of general education curriculum and religious education.

\section{METHODS}

The researcher employed qualitative research techniques in this investigation. In terms of quality, qualitative research differs from other types of research (Moleong, 2014). In qualitative research as a technique, participants are asked to provide as much information as possible, which is subsequently categorized or organized thematically (Creswell, 2018). This indicates that the data is collected in words or representations and does not include any highlights. After the data has been broken down, it is described for others to understand it. According to Saldana, qualitative research is a catch-all term encompassing a variety of naturalistic public-policy investigation methodologies. Information and data were examined subjectively (non-quantitatively) using writings from interviews, field notes, documentation, visual materials such as antiques, photos, videos, web information, and reports of human presence experiences (Sugiyono, 2017).

This study was carried out at SMPIT Al Fatih Jambi, one of SIT. The principal served as the key informant, while the instructor served as the main informant in this study. In order to collect data, researchers used interview protocols, observation sheets or field notes, recordings, and documentation. Principal interviews were conducted three times, whereas teacher interviews were conducted twice. Indicators that are used as guidelines for making interview questions include: 1) HR planning process; 2) selection; 3) training; 4) HR placement; and 5) organizing. The Milles \& Huberman (1994) analysis approach was employed, which consists of three steps: 1) data reduction, 2) data display, and 3) generating conclusions.

\section{FINDINGS AND DISCUSSION}

Based on the research results obtained about how the implementation of teacher HR management in SIT shows that the implementation in SIT has not been said to be perfect in implementing teacher HR management. Why at SMP IT Al Fatih Jambi City is still said to be imperfect in the application of HR management. This can be seen from the following process. First, 
the HR planning process, where HR planning at SMP IT Al Fatih Jambi City is all managed by the chairman of the foundation, namely Mr. BS, not left to the principal. Only the principal carries out the procedures directed by the chairman of the foundation. So, every planning that is made is only the decision of the head of the foundation, not carried out together with the principal and his staff (Elvira, 2021).

According to the interview findings, the chairman of the Foundation did not involve the principal, staffing department, or vice-principal in the HR planning process at SMPIT Al Fatih Jambi City as a leader. The chairman of the Foundation utilizes an autocratic leadership style in HR planning at SMP IT Al Fatih Jambi City. Autocratic leadership is defined by the concentration of authority in the hands of the leader, the dominance of personal decisions and official directives, the absence of subordinate freedom, and long-distance personal ties with subordinates (Lewin, Lippit, \& White, 2019). Leadership style influences HR management, particularly throughout the HR planning process. The following research findings by Kale and Özdelen back up the findings of this investigation.

By strengthening the teacher leadership, schools will better serve both their purposes, as well as the expectations of the school can be better met through shared leadership behaviors. This study may bring awareness to school administrators and teachers to share the particular knowledge and skills manifest as educational leadership. Thus, they might learn or be educated together without the barriers of the traditional emphasis on the continuing role of the principal as the solitary leader in the school" (Kale \& Özdelen, 2014).

This study also supports prior research that found that effective schools rely substantially on their leadership methods (Katzenmeyer \& Moller, 2001; Lieberman et al., 2000; Muijs \& Harris, 2003; Rahmi et al., 2021). The authoritarian leadership style of the chairman of the Foundation is one of the triggers for the imperfect management of teacher human resources at SMPIT Al Fatih Jambi City, according to the explanation of the findings, expert theory, and previous research that supports this research. As a result, leadership has the ability to improve teacher human resource management.

The second is selection. The foundation selects teachers by the demands of the required teachers, and each teacher who applies to SMPIT is chosen solely based on the applicant's abilities. So, among the teaching staff at this time, there are still teachers who do not educate by their fields, such as religious professors with a Bachelor of Laws degree (Elvira, 2021). The HR recruitment process relies heavily on selection in HR management. When a group of applicants has been gathered through various recruitment initiatives, the employment selection process begins (Siagian, 2013). The activity of selecting and determining whether or not candidates are accepted or denied to become employees of the organization is known as selection (Hasibuan, 2013). According to Samsudin, the term "selection" refers to the process of selecting individuals who are currently available with the goal of obtaining qualified and qualified personnel by existing job descriptions or the organization's or company's demands (Samsudin, 2009).

The conclusions of this investigation contradict Garaika \& Margahana's (2019) opinion. According to him, improved selection and recruitment arrangements significantly impact the implementation of other HR tasks like orientation and placement, training and development, career planning and development, job evaluation, and pay. Selection activities must be based on a physical necessity as well as competencies and capabilities that the organization has. If appropriate and carried out according to sound management principles, these operations will be able to keep an organization from having a surplus of personnel unless there are external causes that the organization cannot control.

Based on the findings, expert theory, and prior research, it can be stated that selection in the recruitment process is critical because it allows for the identification of human resources for teachers 
who are better qualified and in line with the scientific field in which they work. In this study, it can be demonstrated that a less severe and well-managed selection procedure causes the human resources of teachers recruited at SMPIT Al Fatih Jambi to be less aligned with the scientific subjects required by the school. As a result, this could be one of the contributing elements to SMPIT Al Fatih Jambi City's poor management of teacher human resources.

Third, for the time being, training is only carried out by one science teacher, particularly a religion teacher, who conducts training online (zoom meeting) and has a group of religious teachers spread throughout the city of Jambi (Elvira, 2021). Training is an endeavor to improve a worker's performance in a specific field of work that is within his control or in a job that is relevant to his employment. Because of technological advances that the firm must react to, this staff training is critical. For instance, the use of computer technology to replace typewriters and other similar devices. HR training aims to increase employees' competencies and capabilities (Syafri \& Alwi, 2014). As a result, training can be defined as a short-term educational activity that uses systematic and organized procedures to teach operational staff technical knowledge and abilities for achieving a certain goal.

Previous research demonstrated that the use of teacher human resource management at MI Al-Islam Bengkulu City, particularly in the training and development program for teacher human resources, was well-executed. The teacher training and human resource development program, on the other hand, has not had a significant impact on the quality of teachers in the learning process (Suparto, 2016). This is in line with a study that found that a lack of training programs contributed to SMPIT Al Fatih Jambi City's poor management of teacher human resources.

Fourth, SMPIT Al Fatih Jambi City has a human resource placement. The placement is also carried out by the foundation's head, rather than the mother, who emphasized at the outset that she only works as a school principal. The foundation is in charge of recruitment and other processes. They only seek to fill openings in specific subjects of study during this procedure so that no lessons are missed. However, the placement is not primarily based on each teacher's expertise in his or her field of study about his or her academic level (Elvira, 2021).

According to Rusby (2016), placement is a recommendation or choice to assign candidates to various occupations based on an assumption about the candidate's ability to succeed in each one. The placement's task is to evaluate candidates and match their qualifications to the job's established requirements. Based on the data and expert perspectives, it can be stated that placement is a followup to the selection process, specifically, placing prospective employees who have been accepted or have passed the job selection process. However, when it came to teacher HR management at SMPIT Al Fatih Jambi City, placement was not based on each teacher's field of study expertise or academic level. As a result, the administration of teacher human resources at SMPIT Al Fatih Jambi City is inefficient.

Fifth, human resource management at SMPIT Al Fatih Jambi City is actually rather well managed, although there are still some flaws; the issue is that activity implementation has not been maximized. As I previously stated, the teachers at this institution are all preoccupied with their own personal interests and have no feeling of responsibility for the load or work that has been placed upon them. As is the case now, when our school is working on school accreditation when preparation for accreditation consists solely of cooperation and a sense of responsibility on the part of the officers in this school. However, all of this did not operate correctly since the professors were too preoccupied with personal interests to think about and prepare what was required for the school's accreditation. So, for the time being, we've decided to engage students from UIN Sultan Thaha Saifuddin Jambi's Department of Islamic Education Management to assist us in preparing for certification (Elvira, 2021).

The division of labor planned to be accomplished by members of the work unit, the formation of an effective work relationship between them, and the supply of a reasonable work environment and facilities to work efficiently are all examples of organizing. The goals of organizing are to: 1) 
develop coordination; 2) make monitoring easier; 3) maximize the benefits of specialization; 4) save money; and 5) increase human relations harmony (Kemendikbud, 2016). In practice, the principle is aided by his deputy in structuring the roles and responsibilities of the principal as a leader in organizing all components of the school, beginning with teachers, administrative personnel, and pupils. Delegation of tasks in an ad hoc manner. The task is done in a systematic, directed, and led manner (Rulitawati et al., 2020). Organizing effectively and efficiently achieves organizational goals, but at SMPIT Al Fatih Jambi City, teacher human resources has not run optimally, as evidenced by a lack of coordination of each teacher on their main tasks and functions, contributing to the imperfect management of teacher human resources.

Based on the interview findings, there are still teachers at SMPIT Jambi City who do not teach in line with their fields. The foundation needs to pay attention to the teacher resources that are available to ensure the school's continued development of students' potential. Furthermore, numerous stakeholders at SMPIT Al Fatih Jambi still lack a sense of responsibility, particularly regarding certain obligations assigned by the principle. Each HR has been given a mandate for their obligations, but not all teachers at SMPIT Jambi City have completed them thus the principal is responsible.

\section{CONCLUSION}

Adopting HR management in SMPIT Al Fatih Jambi has been described as imperfect in its application based on research findings, expert theories, and previous research. This can be seen in the following ways: 1) the chairman of the Foundation's autocratic leadership style is one of the triggers for the ineffective management of teacher human resources at SMPIT Al Fatih Jambi; 2) a less stringent and well-managed selection process causes the human resources of teachers recruited at SMPIT Al Fatih Jambi to be less aligned with the scientific fields required by the school; and 3) a lack of training programs contributes to the ineffective management of teacher human; 4) the placement of teacher human resources is not based on each teacher's expertise in their field of study about their academic level; 5) the lack of coordination of each teacher on their main tasks and functions, which contributes to the ineffective management of teacher human resources at SMPIT Al Fatih Jambi City.

This research will benefit SIT in the future, particularly in terms of the leadership style that the Foundation's chairman must employ in leading SIT to achieve flawless teacher HR management and improve SIT quality. HR planning, selection, training, placement, and organization will be more effective and efficient due to the leadership style. In this disruptive period, SIT can compete with public schools.

\section{REFERENCES}

Anand, S., Fan, V. Y., Zhang, L., Ke, Y., Dong, Z., \& Chen, L. C. (2008). China's Human Resources for Health: Quantity, Quality, and Distribution. The Lancet, 372(9651), 1774-1781.

Asvio, N., Yamin, M., \& Risnita, R. (2019). Influence of Leadership Style, Emotional Intelligence and Job Satisfaction toward Organizational Commitment (Survey at SMA Muhammadiyah South Sumatera). International Journal of Scientific \& Technology Research, 8(8).

Bastian, J. (2009). Falling Short in HR Management. School Administrator, 66(1), 22-23.

Creswell, J. W. (2018). Penelitian Kualitatif \& Desain Riset Edisi 3. Pustaka Pelajar.

Dessler, G. (2014). Fundamentals of Human Resource Management (Third Edit). Pearson.

Elvira, R. (2021). Wawancara Pribadi dengan Kepala Sekolah SMPIT Al Fatih Jambi.

Garaika, \& Margahana, H. (2019). Peran Seleksi (Selection) Tenaga Kerja yang Tepat terhadap Tercapainya Tujuan Organisasi. Jurnal Aktual STIE Trisna Negara, 17(2), 133-141.

Hasibuan, M. S. P. (2013). Organisasi dan Motivasi Dasar Peningkatan Produktivitas. PT. Bumi Aksara.

Ivancevich, J. M. (2010). Human Rresource Management (Internatio). McGraw-Hill.

JSIT. (2016). Pengertian Sekolah Islam Terpadu. https://jsit-indonesia.com/sample- 
page/pengertian-sekolah-islam-terpadu/

Kale, M., \& Özdelen, E. (2014). The Analysis of Teacher Leadership Style according to Teachers' Perception in Primary Schools. Procedia - Social and Behavioral Sciences, 152, 227-232. https://doi.org/10.1016/j.sbspro.2014.09.185

Katzenmeyer, M., \& Moller, G. (2001). Awakening the Sleeping Giant, Helping Teachers Develop as Leaders. Corwin Press.

Kemendikbud. (2016). Pengorganisasian: Model Kemitraan Keluarga dengan Satuan Pendidikan Nonformal. Pusat Pengembangan Pendidikan Anak Usia Dini dan Pendidikan Masyarakat (PPPAUD dan Dikmas) Jawa Barat.

Kemendikbud. (2019). Pendidikan di Indonesia Belajar dari Hasil PISA 2018. Pusat Penilaian Pendidikan Balitbang https://simpandata.kemdikbud.go.id/index.php/s/tLBwAm6zAGGbofK

Lewin, K., Lippitt, R., \& White, R. K. (2019). Basic Styles of Management. https://ceopedia.org/index.php/Lewin,_Lippitt_and_White__basic_styles_of_management

Lieberman, A., Saxl, E. R., \& Miles, M. B. (2000). Teacher Leadership: Ideology and Practice in the JosseyBass Reader on Educational Leadership. JosseyBass.

Marselinus, T. (2011). Sertifikasi dan Profesionalisme Guru. http://50304946.siapsekolah.com/2011/04/28/sertifikasi-dan-profesionalisme-guru/\#.Yar1ItBBw2w

Milles, M. B., \& Huberman, A. M. (1994). Qualitative Data Analysis. Sage Publication.

Moleong, L. J. (2014). Metode Penelitian Kualitatif. Rosdakarya.

Motkuri, V., Vardhan, T. S., \& Ahmad, S. (2018). Quantity and Quality of Human Resources in Health Care: Shortage of Health Workers in India. MPRA Paper, 84332. https://mpra.ub.unimuenchen.de/84332/1/MPRA_paper_84332.pdf

Muijs, D., \& Harris, A. (2003). Teacher Leadership - Improvement through Empowerment? an Overview of the Literature. Educational Management \& Administration, 31(4), 437-448.

Mukhtar, M., Risnita, R., \& Prasetyo, M. A. M. (2020). International Journal of Educational International Journal of Educational Review. International Journal of Educational International Journal of Educational Review, 2(1). https://doi.org/https://doi.org/10.33369/ijer.v2i1.10371

Osagie, R. O., \& Okafor, C. J. (2015). Relationship between Human Resources Management Variables and the Academic Performance of Students in Secondary Schools in Egor Local Government Area, Edo State, Nigeria. Journal of Educational and Social Research, 5(1), 323323.

Priyono. (2010). Manajemen Sumber Daya Manusia. Zifatama Publisher.

Rahmi, Q., Santosa, H., \& Zulaikha, S. (2021). Managerial Competency Model for the Management of Equality Educational Institutions in the Global Era. Al-Ishlah: Jurnal Pendidikan, 13(2), 855-86o. https://doi.org/10.35445/alishlah.v13i2. 634

Ramang. (2020). The Middle School Teacher Resource Management Development. Journal of K6, Education, and Management, 3(2), 138-148. https://doi.org/10.11594/jk6em.03.02.05

Rokhman, F. (2017). Perguruan Tinggi Menyambut Era Disrupsi. https://unnes.ac.id/pakar/perguruan-tinggi-menyambut-era-disrupsi

Rulitawati, R., Ritonga, A. H., \& Hasibuan, L. (2020). International Journal of Educational International Journal of Educational Review. International Journal of Educational International Journal of Educational Review, 2(1). https://doi.org/https://doi.org/10.33369/ijer.v2i1.10381

Runhaar, P. (2017). How can Schools and Teachers Benefit from Human Resources Management? Conceptualising HRM from Content and Process Perspectives. Educational Management Administration \& Leadership, 45(4), 639-656.

Rusby, Z. (2016). Manajemen Sumber Daya Manusia. Pusat Kajian Pendidikan Islam FAI UIR.

Samsudin, S. (2009). Manajemen Sumber Daya Manusia. Pustaka Setia.

Siagian, S. P. (2013). Manajemen Sumber Daya Manusia. PT Bumi Aksara.

Sugiyono. (2017). Metode Penelitian Kualitatif. Alfabeta.

Suparto. (2016). Manajemen Sumber Daya Manusia (SDM) Guru dalam Peningkatan Mutu Pendidikan di Madrasah Ibtidaiyah Al-Islam Kota Bengkulu. An-Nizom, 1(3).

Syafri, W., \& Alwi. (2014). Manajemen Sumber Daya Manusia dalam Organisasi Publik. IPDN Press. 
Tobari, Kristiawan, M., \& Asvio, N. (2018). The Strategy of Headmaster on Upgrading Educational Quality in Asean Economic Community (AEC) Era. International Journal of Scientific and Technology Research, 7(4), 72-79.

Viterouli, M., Belias, D., \& Koustelios, A. (2021). Organizational Performance Enhancement via Adult Education Driven Principles in HR Management. In ECMLG 2021 17th European Conference on Management, 429. 